\title{
Analisis Efisiensi dan Daya Saing Komoditas pada Sistem Usahatani Integrasi Jagung-Sapi di Kabupaten Kupang
}

\section{Analysisof Efficiency and Competitiveness Commodities in Farming Systems Integration Corn-Cattle in Kupang}

\author{
Siviardus Marjaya \\ Program Studi Manajemen Agribisnis Politeknik Pertanian Negeri Kupang \\ Jl. Adisucipto Penfui Kupang, P.O. Box 1152, Kupang 85011 \\ email: smarjaya@yahoo.com
}

\begin{abstract}
Corn-cattle farming systems integration determine the success of a product that can compete in the market, as well as employment opportunities and provide income for farmers. This study aims to analyze the factors that affect production, income, efficiency and competitiveness of the farming system of corn-cattle integration in Kupang district. The analysis model used is the analysis of the production function CobbDouglas Stochastic Frontier model of Battese and Coelli, 1995 with an option for Technical Efficiency Effects Model. Stocastik production function estimation results were technically efficient frontier, with the value of the average technical efficiency is 0.957 for corn, and cattle production is 0.999. Estimation of the cost function shows that the value of cost efficiency (cost efficiency) integration corn-cow farm is greater than one $(C E>1)$ that is 1.009 and 1.268. It means that the use of the cost of production factors on maizecow farm integration should be reduced in order to achieve optimal efficiency. PAM results show that the integration of maize-cow farm financially efficient, have a competitive advantage and can spur the growth of production. While economically or have a comparative advantage.
\end{abstract}

Keywords: Efficiency, Competitiveness Corn-CattleFarm Integration

\section{INTISARI}

Sistem usahatani integrasi jagung-sapi sangat menentukan keberhasilan produk yang bisa bersaing dipasar, sekaligus membuka peluang kesempatan kerja dan memberikan pendapatan bagi petani. Penelitian ini bertujuan untuk menganalisis faktor-faktor yang mempengaruhi produksi, pendapatan, efisiensi dan daya saing sistem usahatani integrasi jagung-sapi di Kabupaten Kupang. Model analisis yang digunakan adalah analisis fungsi produksi Stochastic Frontier Cobb-Douglas model Battese and Coelli, 1995 dengan opsi Technical Efficiency Effect Model. Hasil pendugaan fungsi produksi stocastik frontier secara teknis telah efisien, dengan nilai efisiensi teknis rata- rata adalah 0,957 untuk komoditas jagung, dan ternak sapi potong adalah 0,999. Pendugaan fungsi biaya menunjukan bahwa nilai efisiensi biaya (cost efficiency) usahatani integrasi jagung-sapi lebih besar dari satu $(\mathrm{CE}>1)$ yakni 1.009 dan 1.268. Artinya penggunaan biaya faktor produksi pada usahatani integrasi jagung-sapi harus dikurangi agar dapat mencapai efisiensi yang optimal. Hasil PAM menunjukan bahwa usahatani integrasi jagung-sapi efisien secara finansial, memiliki keunggulan kompetitif dan dapat memacu pertumbuhan produksi. Sedangkan secara ekonomi atau memiliki keunggulan komparatif.

Kata kunci: Efisiensi, Daya Saing Usahatani Integrasi Jagung-Sapi

\section{PENDAHULUAN}

Jagung dan sapi merupakan komoditas utama usahatani lahan kering bagi hamper sebagian besar petani di Nusa Tenggara Timur (NTT). Jagung berperan sebagai sumber pangan utama untuk menjaga ketahanan pangan (food security) dan sapi berperan sebagai sumber pendapatan (cash income), sehingga kedua komoditas ini merupakan bagian yang tidak terpisahkan dari sistem ekonomi masyarakat.

Program integrasi jagung-sapi di NTT ditujukan untuk meningkatkan ketahanan pangan dan ketersediaan ternak sapi serta diarahkan untuk dapat memenuhi kebutuhan ekonomi masyarakat dari produksi pangan jagung maupun ternak sapi 
baik secara regional maupun nasional. Saat ini system integrasi jagung-sapi yang dilaksanakan secara terpadu (integrated farming system), saling mendukung, memperkuat dan saling menguntungkan (sinergis). Dalam sistem integrasi seluruh potensi sumberdaya yang dimiliki masingmasing usahatani dimanfaatkan secara optimal dengan prinsip (zero waste), dengan kata lain tidak ada limbah atau hasil samping yang terbuang percuma.

Potensi limbah pertanian tanaman pangan yang sangat besar, dan sebagian besar belum dimanfaatkan sebagai pakan ternak, namun dengan pola sistem integrasi jagung dan sapi dapat menjadi andalan dalam upaya meningkatkan produktivitas tanaman pangan, ternak, selain itu limbah pertanian dapat meningkatkan kesuburan tanah karena kaya akan kandungan bahan organik.

Penerapan system pertanian terpadu integrasi ternak dan tanaman terbukti sangat efektif dan efisien dalam rangka penyediaan pangan masyarakat. Siklus dan keseimbangan nutrisi serta energi akan terbentuk dalam suatu ekosistem secara terpadu. Dengan demikian akan dapat meningkatkan produktivitas tanaman maupun ternak, efektif, efisien dalam menggunakan tenaga kerja dan waktu kerja, serta dapat menurunkan biaya produksi.

Salah satu indikator dari efisiensi adalah jika sejumlah output tertentu dapat dihasilkan dengan menggunakan sejumlah kombinasi input yang lebih sedikit dan dengan kombinasi input-input tertentu dapat meminimumkan biaya produksi tanpa mengurangi output yang dihasilkan. Dengan biaya produksi yang minimum akan diperoleh harga output yang lebih kompetitif.

Dalam sistem usahatani integrasi jagung-sapi diharapkan agar petani mampu menghasilkan produk yang mempunyai kualitas dan mampu berdaya saing. Daya saing adalah kemampuan produsen memproduksi suatu komoditi dengan mutu yang baik dan biaya yang cukup dan dapat dipasarkan dengan laba yang cukup sehingga dapat melanjutkan kegiatan produksi atau usahanya (Simanjuntak, 1992).

Daya saing suatu komoditas sering diukur dengan menggunakan pendekatan keunggulan komparatif dan kompetitif. Keunggulan komparatif merupakan suatu konsep yang dikembangkan oleh David Ricardo untuk menjelaskan efisiensi alokasi sumberdaya yang terbuka (Krugman dan Obstfeld (2000), Adnyaya \& Kariyasa (2003). Menurut Simatupang (1991); Sudaryanto dan Simatupang (1993) konsep keunggulan komparatif merupakan ukuran daya saing potensial apabila perekonomian tidak mengalami distorsi sama sekali.

\section{BAHAN DAN METODE}

\section{Lokasi, Sampel dan Waktu Penelitian}

Penelitian ini dilaksanakan di lima kecamatan, 16 desa dan 160 rumah tangga tani yang mengusahakan komoditas unggulan jagung dan sapi yang terintegrasi dalam satu kesatuan sistem di Kabupaten Kupang. Waktu penelitian dimulai dari bulan April sampai Desember 2011.

\section{Metode Analisis Data}

\section{Analisis Fungsi Produksi}

Penelitian ini menggunakan fungsi produksi Cobb-Douglas yakni untuk mengetahui hubungan antara input-output serta mengukur pengaruh dari berbagai perubahan harga dari input terhadap produksi.

\section{a. Model fungsi produksi jagung}

dan

$$
\begin{aligned}
\operatorname{Ln}_{\text {Projg }}= & \alpha_{0}+\alpha_{1} \ln _{\text {Luas }}+\alpha_{2} \ln _{\text {Bnh }}+\alpha_{3} \ln _{P k d g}+\alpha_{4} \ln _{\text {Urea }}+\alpha_{5} \ln _{S P 36}+\alpha_{6} \ln _{K c l}+\alpha_{7} \ln _{P e s t}+\alpha_{8} \ln _{T K} \\
& +\alpha_{10} \ln _{\text {Prosp }}+\delta D 1+u_{i}+v_{i} \ldots \ldots \ldots \ldots \ldots . . . .(8)
\end{aligned}
$$

\section{Keterangan:}

$\begin{array}{ll}\ln \text { Projg } & =\text { produksi jagung }(\mathrm{kg}) \\ \ln \text { Luas } & =\text { luas lahan (hektar) } \\ \ln \text { Bnh } & =\text { jumlah benih jagung }(\mathrm{kg}) \\ \ln \text { Pkdg } & =\text { jumlah pupuk kandang }(\mathrm{kg}) \\ \ln \text { Urea } & =\text { jumlah pupuk urea }(\mathrm{kg}) \\ \ln \mathrm{SP} 36 & =\text { jumlah pupuk SP36 }(\mathrm{kg}) \\ \ln \mathrm{Kcl} & =\text { jumlah pupuk Kcl }(\mathrm{kg}) \\ \ln \text { Pest } & =\text { jumlah pestisida }(\mathrm{ltr})\end{array}$

In TK = jumlah tenaga kerja (OK)

$\ln$ Prosp = jumlah produksi sapi $(\mathrm{kg})$

$\mathrm{D} \quad=$ dummy integrasi

ui = variabel error yang dapat dikendalikan

vi, $\quad=$ variabel error yang tidak dapat dikendalikan

$\alpha \quad=$ koefisien input variabel i 
b. Model fungsi produksi sapi potong

Model fungsi produksi sapi potong dengan
OLS dan MLE adalah:

$$
\begin{aligned}
& \ln _{P s p}=\alpha 0+\alpha_{1} \ln _{s p b}+\alpha_{2} \ln n_{T b j g}+\alpha_{3} \ln _{J r m}+\alpha_{4} \ln _{H j l n}+\alpha_{5} \ln _{O b t}+\alpha_{6} \ln _{V i t}+\alpha_{7} \ln _{T K}+\alpha_{7} \ln \operatorname{lrodjg}_{P r} \\
& +\delta D_{1}+u_{i}+v_{i}
\end{aligned}
$$

\section{Keterangan:}

$$
\begin{array}{ll}
\ln \operatorname{Prod}_{\mathrm{sp}} & =\text { jumlah produksi sapi }(\mathrm{kg}) \\
\ln \mathrm{spb} & =\text { jumlah sapi bakalan }(\mathrm{kg}) \\
\ln \mathrm{Tbjg} & =\text { jumlah tebon jagung }(\mathrm{kg}) \\
\ln \mathrm{Jrm} & =\text { jumlah jerami padi }(\mathrm{kg}) \\
\ln \mathrm{Hjln} & =\text { jumlah hijauan lain }(\mathrm{kg}) \\
\ln \mathrm{Obt} & =\text { jumlah obat-obatan }(\mathrm{ml}) \\
\ln \mathrm{Vit} & =\text { jumlah vitamin }(\mathrm{ampul}) \\
\ln \mathrm{TK} & =\text { jumlah tenaga kerja }(\mathrm{OK}) \\
\ln \text { Prodjg } & =\text { produksi jagung }(\mathrm{kg}) \\
\delta \mathrm{D} & =\text { dummy integrasi } \\
u i & =\text { variabel error yang dapat }
\end{array}
$$

$$
\begin{aligned}
& \text { dikendalikan } \\
& \text { vi, } \quad=\text { variabel error yang tidak dapat } \\
& \text { dikendalikan } \\
& \alpha \quad=\text { koefisien input variabel-i }
\end{aligned}
$$

\section{Analisis Fungsi Biaya}

Fungsi biaya yang digunakan untuk mengukur pendapatan sistem usahatani integrasi jagung-sapi adalah sebagai berikut:

\section{a. Model fungsi biaya usahatani jagung:}

$$
\begin{aligned}
& \ln _{C_{j g}}=\alpha_{0}+\alpha_{1} H_{s w l}+\alpha_{2} H_{b n h}+\alpha_{3} H_{p k d g}+\alpha_{4} H_{u r e a}+\alpha_{5} H_{S P 36}+\alpha_{6} H_{K c l}+\alpha_{7} H_{p e s t}+\alpha_{8} U_{T K}+ \\
& \operatorname{Prod}_{s p}+v_{i}+u i
\end{aligned}
$$

\section{Keterangan:}

$\begin{array}{ll}\ln \mathrm{C}_{\mathrm{Jg}} & =\text { biaya jangka pendek jagung } \\ \ln \mathrm{H}_{\mathrm{Swl}} & =\text { harga sewa lahan }(\mathrm{Rp}) \\ \ln \mathrm{H}_{\mathrm{bnh}} & =\text { harga benih jagung }(\mathrm{Rp}) \\ \ln \mathrm{H}_{\mathrm{pkndg}} & =\text { harga pupuk kandang }(\mathrm{Rp}) \\ \ln \mathrm{H}_{\text {urea }} & =\text { harga pupuk urea }(\mathrm{Rp}) \\ \ln \mathrm{H}_{\mathrm{SP} 36} & =\text { harga pupuk SP36 }(\mathrm{Rp}) \\ \ln \mathrm{H}_{\mathrm{Kcl}} & =\text { harga pupuk Kcl }(\mathrm{Rp}) \\ \ln \mathrm{H}_{\mathrm{pest}} & =\text { harga pestisida }(\mathrm{Rp})\end{array}$

$$
\begin{aligned}
& \text { ln } \mathrm{H}_{\mathrm{TK}} \quad=\text { upah tenaga } \operatorname{kerja}(\mathrm{Rp}) \\
& \ln \operatorname{Prod}_{\mathrm{sp}}=\text { produksi sapi }(\mathrm{kg}) \\
& u i \quad=\text { variabel error yang dapat } \\
& \text { dikendalikan } \\
& \text { vi, } \quad=\text { variabel error yang tidak dapat } \\
& \text { dikendalikan } \\
& =\text { koefisien input variabel }
\end{aligned}
$$

b. Model fungsi biaya sapi potong

$$
\begin{aligned}
& \ln C_{s p}=\alpha_{0}+\alpha_{1} H_{s p b}+\alpha_{2} H_{k d n g}+\alpha_{3} H_{t b j g}+\alpha_{4} H_{j r m}+\alpha_{5} H_{h j l n}+\alpha_{6} H_{o b t}+a_{7} H_{v i t}+\alpha_{8} H_{T K}+ \\
& \alpha_{9} H_{\text {trans }}+\alpha_{10} \operatorname{Prod}_{j g} \varepsilon+v_{i}+u_{i}
\end{aligned}
$$

Keterangan:

$\begin{array}{ll}\ln \mathrm{C}_{\mathrm{sp}} & =\text { biaya jangka pendek usaha } \\ & \text { penggemukan sapi (Rp) } \\ \ln \mathrm{H}_{\mathrm{spb}}= & \text { harga sapi bakalan (Rp) } \\ \ln \mathrm{H}_{\mathrm{kndg}}= & \text { harga pembuatan kandang (Rp) } \\ \ln \mathrm{H}_{\mathrm{tbjg}}= & \text { harga tebon jagung (Rp) } \\ \ln \mathrm{H}_{\mathrm{jrm}}=\text { harga jerami padi (Rp) } \\ \ln \mathrm{H}_{\mathrm{hjln}}=\text { harga hijauan lain (Rp) } \\ \ln \mathrm{H}_{\mathrm{obt}}=\text { harga obat-obatan (Rp) } \\ \ln \mathrm{H}_{\mathrm{vit}}=\text { harga vitamin (Rp) } \\ \ln \mathrm{H}_{\mathrm{TK}}=\text { upah tenaga kerja }(\mathrm{Rp})\end{array}$

$$
\begin{aligned}
& \text { ln } \left.\mathrm{H}_{\text {trans }} \quad=\text { harga transportasi ( } \mathrm{Rp}\right) \\
& \ln \operatorname{Prod}_{\mathrm{jg}}=\text { produksi jagung }(\mathrm{kg}) \\
& u_{i} \quad=\text { variabel error yang dapat } \\
& \text { dikendalikan } \\
& \text { = variabel error yang tidak dapat } \\
& \text { dikendalikan } \\
& =\text { koefisien input variabel } \mathrm{i}
\end{aligned}
$$

\section{Analisis Efisiensi}

a. Efisiensi teknis

Analisis efisiensi teknis dapat diukur dengan menggunakan rumus berikut: 
di mana $T E i$ adalah efisiensi teknis petani ke-i, $\exp (-E[u i \mid \varepsilon])$ adalah nilai harapan (mean) dari $u i$ dengan syarat $\varepsilon i$, jadi $0 \leq T E i \leq 1$. Variabel $u i$ yang digunakan untuk mengukur efek inefisiensi teknis diasumsikan bebas dan distribusinya normal dengan $N\left({ }_{i}, \sigma^{2}\right)$. Pengujian parameter stochastic frontier dan efek inefisiensi teknis yakni untuk menduga seluruh parameter $a_{0}, a_{j}$, varians $u_{i}$ dan $v_{i}$ dengan dilakukan dengan menggunakan metode Maximum Likelihood (MLE), pada tingkat kepercayaan $\alpha 5$ persen. Hasil pengolahan program FRONTIER 4.1 akan memberikan nilai perkiraan varians dalam bentuk parameterisasi sebagai berikut:

$$
\begin{aligned}
& \sigma 2=\sigma_{v}^{2}+\sigma_{u}^{2} . \\
& \mathrm{Y}=\frac{\sigma_{u}^{2}}{\sigma_{v}^{2}} \ldots \ldots \ldots \ldots
\end{aligned}
$$

Parameter dari varians ini dapat mencari nilai $Y$, oleh sebab itu $0 \leq \gamma \leq 1$. Nilai parameter $Y$ merupakan kontribusi dari efisiensi teknis di dalam efek residual total.

\section{b. Efisiensi harga (alokatif)}

Efisiensi alokatif dan ekonomis diperoleh melalui analisis dari sisi input produksi, menggunakan harga input yang berlaku di tingkat petani. Fungsi produksi yang digunakan sebagai biaya frontier (isocost frontier) hasil penurunan fungsi produksi stochastic frontier Efisiensi alokatif (AE) merupakan rasio dari efisiensi ekonomis dan efisiensi teknis, dapat ditulis secara matematis adalah:

$$
\mathrm{EA}=\frac{E E}{E T},
$$

Keterangan :

$\mathrm{EA}=$ efisiensi alokatif

$\mathrm{EE}=$ efisiensi ekonomi jagung

$\mathrm{ET}=$ efisiensi teknis jagung

\section{c. Efisiensi ekonomi}

Menurut Jondrow et al. (1982) dalam Ogundari dan Ojo (2006), efisiensi ekonomi (EE) didefinisikan sebagai rasio antara biaya total produksi minimum yang diobservasi $\left(C^{*}\right)$ dengan total biaya produksi aktual $(C)$, seperti pada persamaan (16).

$$
E E=\frac{C^{*}}{C}=\frac{E\left(C_{i} \mid u_{i}=O_{i}, Y_{i}, P_{i}\right)}{E\left(C_{i}, \mid u_{i}, Y_{i}, P_{i}\right)}=\mathrm{E}\left[u_{i} / \varepsilon\right] \ldots \ldots
$$

Keterangan : EE bernilai $0 \leq \mathrm{EE} \leq 1$.

\section{HASIL DAN PEMBAHASAN}

\section{Analisis Fungsi Produksi}

Analisis fungsi produksi frontier melalui fungsi produksi Cobb-Douglas dapat dilakukan untuk mengetahui gambaran secara teknis terhadap kegiatan sistem usahatani integrasi jagung-sapi di Kabupaten Kupang.

\section{a. Pendugaan fungsi produksi jagung dengan OLS dan MLE}

Hasil analisis fungsi produksi jagung baik dengan OLS maupun MLE didapat nilai sigma squared $(\sigma 2)$ adalah 8.536 dan 5.621, nilai gamma ( $\gamma$ ) adalah 2.132 dan 0.723 , sedangkan nilai $\log$ likelihood function adalah -3.031, dan nilai LR test of the one-sided error adalah 1.600.

Nilai sigma squared (б2) 8.536 dan 5.621 secara statistik menunjukkan bahwa $85,36 \%$ dan $56,21 \%$ dari variabel galat di dalam fungsi produksi menggambarkan efisiensi teknis petani atau variasi hasil diantara petani responden disebabkan oleh perbedaan dari efisiensi teknis dan sisanya disebabkan oleh efek-efek stochastic dan kesalahan dalam pemodelan.

Nilai dugaan parameter gamma ( $\gamma)$ mengindikasikan ratio antara deviasi inefisiensi teknis $\left(u_{i}\right)$ terhadap deviasi yang mungkin disebabkan oleh faktor acak $\left(v_{i}\right)$. Secara statistik nilai dugaan gamma $(\gamma)$ adalah 0.723 mendekati 1 yang berarti bahwa 72,3 persen dari kesalahan (error) dalam fungsi produksi disebabkan oleh perbedaan efisensi teknis, sedangkan sisanya 27,7 persen disebabkan oleh variabel kesalahan acak.

Sedangka nilai ratio generalized likelihood (LR) dari fungsi produksi stochastic frontier untuk komoditas jagung adalah 0.160, dimana signifikan pada $\alpha=0,05$ persen yang berarti ada efek inefisiensi teknis dalam model pada teknologi tertentu.

\section{b. Pendugaan fungsi produksi sapi dengan OLS dan MLE}

Pendugaan parameter fungsi produksi stochastic frontier dengan metode OLS dan MLE pada usaha penggemukan sapi memberikan gambaran kinerja rata-rata dari proses produksi petani pada tingkat teknologi yang digunakan. 
Tabel 1. Pendugaan Fungsi Produksi Teknis Usahatani Jagung Dengan OLS dan MLE, 2010

\begin{tabular}{|c|c|c|c|c|c|c|c|}
\hline \multirow[b]{2}{*}{ Input Variabel } & \multirow[b]{2}{*}{ Simbol } & \multicolumn{3}{|c|}{ OLS } & \multicolumn{3}{|c|}{ MLE } \\
\hline & & $\begin{array}{l}\text { Coef- } \\
\text { ficient }\end{array}$ & $\begin{array}{c}\text { Std } \\
\text { Eror }\end{array}$ & t-ratio & $\begin{array}{l}\text { Coef- } \\
\text { ficient }\end{array}$ & $\begin{array}{c}\text { Std } \\
\text { Eror }\end{array}$ & t-ratio \\
\hline ln Intersep & $\alpha_{0}$ & $0.222 * * *$ & 0.608 & 3.65 & $0.231 * *$ & 0.985 & 2.345 \\
\hline In Luas lahan jagung (ha) & $\alpha_{1}$ & $0.299 * * *$ & 0.681 & 4.39 & $0.985 * * *$ & 0.990 & 2.683 \\
\hline In Jumlah benih jagung ( $\mathrm{kg}$ ) & $\alpha_{2}$ & $0.136 * *$ & 0.659 & 2.07 & $0.158 * *$ & 0.884 & 1.788 \\
\hline In Jumlah pupuk kandang (kg) & $\alpha_{3}$ & $0.163 * * *$ & 0.512 & 3.18 & $0.167 * * *$ & 0.522 & 3.209 \\
\hline In Jumlah pupuk Urea (kg) & $\alpha_{4}$ & $-0.812 * * *$ & 0.281 & -2.88 & $-0.691 * *$ & 0.320 & -2.154 \\
\hline In Jumlah pupuk SP36 (kg) & $\alpha_{5}$ & $0.658 * * *$ & 0.330 & 1.99 & $0.729 * *$ & 0.339 & 2.149 \\
\hline In Jumlah pupuk KCL (kg) & $\alpha_{6}$ & $0.613 * *$ & 0.354 & 1.73 & $0.396^{*}$ & 0.393 & 1.007 \\
\hline In Jumlah pestisida (liter) & $\alpha_{7}$ & $0.397 * *$ & 0.361 & 1.09 & $0.502 *$ & 0.379 & 1.323 \\
\hline In Jumlah tenaga kerja (HOK) & $\alpha_{8}$ & $0.124 * * *$ & 0.594 & 2.08 & $0.136 * *$ & 0.593 & 2.291 \\
\hline In Jumlah produksi sapi (kg) & $a_{9}$ & $0.600 * *$ & 0.457 & 1.31 & $0.758 * *$ & 0.542 & 1.398 \\
\hline Dummy intergrasi & D1 & $0.319 * * *$ & 0.909 & 3.50 & $0.293 * * *$ & 0.107 & 2.723 \\
\hline Sigma-squared $\left(\sigma^{2} \mathrm{~s}=\sigma^{2} \mathrm{v}+\sigma^{2} \mathrm{u}\right)$ & & & & & 8.536 & 0.151 & 5.621 \\
\hline $\operatorname{Gamma}\left(\gamma=\sigma^{2} u+\sigma^{2} s\right)$ & & & & & 0.121 & 0.168 & 7.232 \\
\hline log likehood fuction & & & & & & & -3031 \\
\hline LR test of one-sidded error & & & & & & & 1.600 \\
\hline Mean efficiency $=$ & & & & & & & 0.957 \\
\hline
\end{tabular}

Sumber: Data primer diolah, 2011

Keterangan :*** = nyata pada $\alpha=0,01 ; * *=$ nyata pada $\alpha=0,05 ; *=$ nyata pada $\alpha=0,10$

$\mathrm{t}_{\text {-Tabel }} \alpha 0,01 \%=2,576 \mathrm{t}_{\text {-Tabel }} \alpha 0,05 \%=1,645 \mathrm{t}_{\text {-Tabel }} \alpha 0,1 \%=1,282$

Tabel 2. Pendugaan Fungsi Produksi Usaha Ternak Sapi Potong Dengan OLS dan MLE, 2010

\begin{tabular}{|c|c|c|c|c|c|c|c|}
\hline \multirow[b]{2}{*}{ Input Variabel } & \multirow[b]{2}{*}{ Simbol } & \multicolumn{3}{|c|}{ OLS } & \multicolumn{3}{|c|}{ MLE } \\
\hline & & $\begin{array}{l}\text { Coef- } \\
\text { ficient }\end{array}$ & $\begin{array}{c}\text { Std } \\
\text { Eror }\end{array}$ & t-ratio & $\begin{array}{l}\text { Coef- } \\
\text { ficient }\end{array}$ & $\underset{\text { Eror }}{\text { Std }}$ & t-ratio \\
\hline Intersep & $\alpha_{0}$ & $1.047 * * *$ & 0.270 & 3.874 & $1.048 * * *$ & 0.282 & 3.709 \\
\hline ln Jumlah sapi bakalan (kg) & $\alpha_{1}$ & $0.171 * * *$ & 0.402 & 4.264 & $0.171 * * *$ & 0.390 & 4.388 \\
\hline In Jumlah tebon jagung $(\mathrm{kg})$ & $a_{2}$ & $0.665^{* *}$ & 0.353 & 1.883 & $0.665 * *$ & 0.341 & 1.949 \\
\hline ln Jumlah jerami padi (kg) & $a_{3}$ & $0.275^{*}$ & 0.238 & 1.155 & $0.275^{*}$ & 0.231 & 1.189 \\
\hline In Jumlah hijauan lain (kg) & $a_{4}$ & $0.620 * * *$ & 0.212 & 2.920 & $0.620 * * *$ & 0.204 & 3.033 \\
\hline ln Jumlah obat-obatan (ml) & $a_{5}$ & $0.575 * * *$ & 0.614 & 9.363 & $0.575 * * *$ & 0.597 & 9.639 \\
\hline ln Jumlah vitamin (ampul) & $a_{6}$ & $0.229 * * *$ & 0.562 & 4.073 & $0.229 * * *$ & 0.539 & 4.245 \\
\hline ln Jumlah tenaga kerja (HOK) & $\alpha_{7}$ & $0.103^{* *}$ & 0.464 & 2.233 & $0.103^{* *}$ & 0.455 & 2.276 \\
\hline ln Jumlah produksi jagung (kg) & $\alpha_{8}$ & $0.851^{\mathrm{ns}}$ & 0.196 & 0.432 & $0.851^{\mathrm{ns}}$ & 0.189 & 0.450 \\
\hline Sigma-squared $\left(\sigma^{2} \mathrm{~s}=\sigma^{2} v+\sigma^{2} \mathrm{u}\right)$ & & & & & 0.169 & 0.196 & 8.603 \\
\hline $\operatorname{Gamma}\left(\gamma=\sigma^{2} u+\sigma^{2} s\right)$ & & & & & 0.634 & 0.194 & 0.327 \\
\hline log likehood fuction & & & & & & & 9.921 \\
\hline Mean efficiency $=$ & & & & & & & 0.999 \\
\hline
\end{tabular}

Sumber: Data primer diolah, 2011

Keterangan :*** = nyata pada $\alpha=0,01 ; * *=$ nyata pada $\alpha=0,05 ; *=$ nyata pada $\alpha=0,10$

$\mathrm{t}_{\text {-Tabel }} \alpha 0,01 \%=2,576 \mathrm{t}_{\text {-Tabel }} \alpha 0,05 \%=1,645 \mathrm{t}_{\text {-Tabel }} \alpha 0,1 \%=1,282$

Besaran nilai sigma squared (o2) adalah 0,860 secara statistik nilai yang diperoleh tersebut menunjukkan bahwa 86,0 persen dari variabel galat di dalam fungsi produksi menggambarkan efisiensi teknis petani atau variasi hasil diantara petani responden disebabkan oleh perbedaan dari efisiensi teknis dan sisanya sebesar 14,0 persen disebabkan oleh efek-efek stochastic.

Nilai gamma $(\gamma)$ usaha sapi potong adalah 0,327 nyata pada taraf $\alpha=5 \%$. Gamma mengindikasikan keberadaan efisiensi teknis dalam proses produksi, atau variasi hasil yang disebabkan oleh perbedaan efisensi teknis. Sedangkan nilai log likelihood function adalah 
0,992. Fenomena tersebut membuktikan bahwa hampir semua variasi output dari produksi batas dianggap sebagai akibat dari tingkat pencapaian efisiensi teknis yang berkaitan dengan soal manajerial dalam pengelolaan usahatani.

Tingkat efisiensi teknis rata-rata yang dicapai dari usaha penggemukan sapi potong adalah 0,999 , artinya bahwa secara keseluruhan rata-rata produktivitas yang dicapai oleh usaha ternak sapi potong ini adalah 99,9\% dari frontiernya, artinya usaha penggemukan sapi ini sudah efisien sehingga perlu dipertahankan namun tetap memperbaiki sistem pengelolaannya.

\section{Analisis Fungsi Biaya}

\section{a. Analisis fungsi biaya usahatani jagung}

Hasil analisis OLS dan MLE menunjukan bahwa variabel harga benih jagung, pupuk urea, pupuk SP36, pestisida, dan upah tenaga kerja berpengaruh nyata pada taraf kepercayaan $(\alpha=1 \%)$ dengan nilai koefisien regresi masing-masing sebesar $0.135,0.113,0.129,0.187$, dan 0.131, sementara harga sewa lahan, harga pupuk KCL dan produksi sapi berpengaruh nyata pada taraf kepercayaan $(\alpha=5 \%)$ dengan nilai koefisien regresi masing-masing sebesar $0.121,0.560$, dan 0.120 , sedangkan harga pupuk kandang dan produksi sapi menunjukan pengaruh tidak nyata.

Besaran nilai Sigma-squared $(\sigma)$ diperoleh 0,498 atau $49,8 \%$ artinya besarnya kontribusi semua variabel terhadap pendapatan jangka pendek sebesar 49,8\% (50\%), sedangkan sisa 50\% di sebabkan oleh faktor lain. Nilai gamma $(\gamma)$ adalah 0,384 nyata pada taraf $\alpha=5 \%$. Gamma mengindikasikan keberadaan efisiensi biaya dalam proses produksi, atau variasi hasil yang disebabkan oleh perbedaan efisensi biaya.

Tabel 3. Pendugaan Fungsi Biaya Usahatani Jagung Dengan OLS dan MLE, 2011

\begin{tabular}{|c|c|c|c|c|c|c|c|}
\hline \multirow[b]{2}{*}{ Input Variabel } & \multirow[b]{2}{*}{ Simbol } & \multicolumn{3}{|c|}{ OLS } & \multicolumn{3}{|c|}{ MLE } \\
\hline & & $\begin{array}{l}\text { Coef- } \\
\text { ficient }\end{array}$ & $\begin{array}{c}\text { Std } \\
\text { Eror }\end{array}$ & t-ratio & $\begin{array}{l}\text { Coef- } \\
\text { ficient }\end{array}$ & $\begin{array}{c}\text { Std } \\
\text { Eror }\end{array}$ & t-ratio \\
\hline ln Intersep & $\alpha_{0}$ & $0.681 * * *$ & 0.827 & 8.234 & $0.681 * * *$ & 0.143 & 4.7333 \\
\hline ln Harga sewa lahan (Rp) & $\alpha_{1}$ & $0.121 * *$ & 0.550 & 2.203 & $0.121 * *$ & 0.491 & 2.466 \\
\hline In Harga benih jagung (Rp) & $\alpha_{2}$ & $0.135^{* * *}$ & 0.416 & 3.260 & $0.135^{* * *}$ & 0.398 & 3.400 \\
\hline $\begin{array}{l}\text { In Harga pupuk kandang } \\
\text { (Rp) }\end{array}$ & $\alpha_{3}$ & $0.393^{\mathrm{ns}}$ & 0.374 & 1.049 & $0.393^{\text {ns }}$ & 0.362 & 1.088 \\
\hline ln Harga pupuk urea (Rp) & $a_{4}$ & $0.113^{* * *}$ & 0.383 & 2.968 & $0.113 * * *$ & 0.343 & 3.300 \\
\hline ln Harga pupuk SP36 (Rp) & $\alpha_{5}$ & $0.129 * * *$ & 0.432 & 2.994 & $0.129 * * *$ & 0.415 & 3.111 \\
\hline In Harga pupuk KCL (Rp) & $\alpha_{6}$ & $0.560^{* * *}$ & 0.318 & 1.760 & $0.560^{* * *}$ & 0.308 & 1.811 \\
\hline ln Harga pestisida (Rp) & $\alpha_{7}$ & $0.131 * * *$ & 0.442 & 2.969 & $0.131 * * *$ & 0.405 & 3.244 \\
\hline ln Upah tenaga kerja (Rp) & $\alpha_{8}$ & $0.187 * * *$ & 0.534 & 3.498 & $0.187 * * *$ & 0.498 & 3.755 \\
\hline ln Produksi sapi (kg) & $\alpha_{9}$ & $0.120^{\mathrm{ns}}$ & 0.102 & 1.176 & $0.120^{\mathrm{ns}}$ & 0.989 & 1.211 \\
\hline Sigma-squared $\left(\sigma^{2} \mathrm{~s}=\sigma^{2} v+\sigma^{2} \mathrm{u}\right)$ & & & & 0.159 & 0.149 & 0.300 & 4.986 \\
\hline $\operatorname{Gamma}\left(\gamma=\sigma^{2} u+\sigma^{2} s\right)$ & & & & & 0.986 & 0.256 & 3.846 \\
\hline log likehood fuction & & & & & & & -7.507 \\
\hline LR test of one-sidded error & & & & & & & 3.376 \\
\hline Mean efficiency $=$ & & & & & & & 1.009 \\
\hline
\end{tabular}

Sumber: Data primer diolah, 2011

Keterangan :*** = nyata pada $\alpha=0,01 ; * *=$ nyata pada $\alpha=0,05 ; *=$ nyata pada $\alpha=0,10$

$\mathrm{t}_{-}{ }_{\text {Tabel }} \alpha 0,01 \%=2,576 \mathrm{t}^{-}{ }_{\text {Tabel }} \alpha 0,05 \%=1,645 \mathrm{t}_{\text {Tabel }} \alpha 0,1 \%=1,282$

Besaran nilai log likelihood function dari efisiensi biaya stochastic frontier usaha jagung adalah $-0,750$. Artinya hampir semua variasi output dari produksi batas dianggap sebagai akibat dari tingkat pencapaian efisiensi biaya yang berkaitan dengan soal manajerial dalam pengelolaan usahatani. Sedangkan nilai ratio generalized likelihood (LR) dari efisiensi biaya stochastic frontier untuk komoditas jagung adalah
0.337 , dimana signifikan pada $\alpha=0,05$ persen yang berarti ada efek in-efisiensi biaya dalam model pada teknologi tertentu.

Tingkat efisiensi biaya rata-rata yang dicapai adalah satu $(\mathrm{EB}=1)$, artinya bahwa secara keseluruhan rata-rata keuntungan yang dicapai oleh usahatani jagung di daerah penelitian adalah $100 \%$ dari frontiernya yakni keuntungan maksimum yang dapat dicapai dengan sistem 
pengelolaan yang baik.

\section{b. Analisis fungsi biaya usaha penggemukan sapi potong}

Tabel 4 memperlihatkan hasil pendugaan biaya stochastic frontier pada usaha penggemukan sapi potong dengan sepuluh variable penjelas.

Hasil analisis frontier bahwa variabel harga sapi bakalan, harga hijauan lain, harga obatobatan, harga vitamin dan transportasi berpengaruh nyata $(\alpha=5 \%)$ terhadap pendapatan usaha penggemukan sapi potong, dengan nilai koefisien regresi masing-masing sebesar 0.827 , $0.416,-0.949,0.838$ dan -0.446 , sementara variabel harga pembuatan kandang, harga tebon jagung, upah tenaga kerja dan produksi jagung menunjukan pengaruh tidak nyata.

Besaran nilai Sigma-squared $(\sigma)$ diperoleh 9.813 atau $98,13 \%$ artinya besarnya kontribusi semua variable terhadap pendapatan jangka pendek sebesar $98,13 \%$, sedangkan sisa $1,87 \%$ di sebabkan oleh faktor lain. Nilai gamma $(\gamma)$ efisiensi biaya usaha penggemukan sapi potong 5.045 atau $50,45 \%$. Artinya terdapat variasi hasil yang disebabkan oleh perbedaan efisensi biaya. Sedangkan nilai log likelihood function 6.513. Besaran nilai ratio generalized likelihood (LR) adalah 9.977, dimana signifikan pada $\alpha=0,01$ persen yang berarti ada efek inefisiensi biaya dalam model pada teknologi tertentu.

Tabel 4. Pendugaan Fungsi Biaya Usaha Sapi Potong/Unit Usaha Ternak Dengan Metode OLS dan MLE, 2011.

\begin{tabular}{|c|c|c|c|c|c|c|c|}
\hline \multirow[b]{2}{*}{ Input Variabel } & \multirow[b]{2}{*}{ Simbol } & \multicolumn{3}{|c|}{ OLS } & \multicolumn{3}{|c|}{ MLE } \\
\hline & & $\begin{array}{l}\text { Coef- } \\
\text { ficient }\end{array}$ & $\begin{array}{c}\text { Std } \\
\text { Eror }\end{array}$ & t-ratio & $\begin{array}{l}\text { Coef- } \\
\text { ficient }\end{array}$ & $\begin{array}{c}\text { Std } \\
\text { Eror }\end{array}$ & t-ratio \\
\hline ln Intersep & $\alpha_{0}$ & $2.379 * * *$ & 0.265 & 8.950 & $2.534^{* * *}$ & 0.334 & 7.586 \\
\hline In Harga sapi bakalan (Rp) & $\alpha_{1}$ & $0.329 * * *$ & 0.741 & 4.435 & $0.827^{* * *}$ & 0.304 & 2.716 \\
\hline $\begin{array}{l}\text { ln Harga pembuatan } \\
\text { kandang (Rp) }\end{array}$ & $a_{2}$ & $-0.216^{\mathrm{ns}}$ & 0.256 & -0.845 & $-0.840^{\mathrm{ns}}$ & 0.106 & -0.787 \\
\hline ln Harga tebon jagung (Rp) & $\alpha_{3}$ & $0.152^{\mathrm{ns}}$ & 0.193 & 0.789 & $0.149 * *$ & 0.898 & 1.662 \\
\hline In Harga jerami padi (Rp) & $a_{4}$ & $0.345^{*}$ & 0.258 & 1.337 & $-0.144^{\mathrm{ns}}$ & 0.113 & -1.273 \\
\hline ln Harga hijauan lain (Rp) & $a_{5}$ & $-0.654 * * *$ & 0.247 & -2.639 & $-0.416 * * *$ & 0.972 & -4.281 \\
\hline ln Harga obat-obatan (Rp) & $a_{6}$ & $-0.382 *$ & 0.264 & -1.443 & $-0.446 * * *$ & 0.116 & -3.818 \\
\hline In Harga vitamin (Rp) & $a_{7}$ & $0.240 * * *$ & 0.702 & 3.422 & $0.838^{* * *}$ & 0.133 & 6.280 \\
\hline $\begin{array}{l}\text { In Upah tenaga kerja } \\
(\mathrm{HOK})\end{array}$ & $a_{8}$ & $0.594^{\mathrm{ns}}$ & 0.339 & 0.175 & $0.230^{\mathrm{ns}}$ & 0.199 & 1.153 \\
\hline ln Ongkos transportasi (Rp) & $a_{9}$ & $-0.880 * * *$ & 0.102 & -8.606 & $-0.949 * * *$ & 0.280 & -33.80 \\
\hline In Produksi jagung $(\mathrm{kg})$ & $\alpha_{10}$ & $-0.955^{\mathrm{ns}}$ & 0.309 & -0.308 & $0.108^{\text {ns }}$ & 0.140 & 0.772 \\
\hline Sigma-squared $\left(\sigma^{2} \mathrm{~s}=\sigma^{2} \mathrm{v}+\sigma^{2} \mathrm{u}\right)$ & & & & 5.195 & & 0.102 & 9.813 \\
\hline $\operatorname{Gamma}\left(\gamma=\sigma^{2} u+\sigma^{2} s\right)$ & & & & & & 0.198 & 5.045 \\
\hline log likehood fuction & & & & 15.254 & & & 6.513 \\
\hline LR test of one-sidded error & & & & & & & 9.977 \\
\hline Mean efficiency = & & & & & & & 1.286 \\
\hline
\end{tabular}

Sumber: Data primer diolah, 2011

Keterangan :*** = nyata pada $\alpha=0,01 ; * *=$ nyata pada $\alpha=0,05 ; *=$ nyata pada $\alpha=0,10$

$\mathrm{t}_{\text {-Tabel }} \alpha 0,01 \%=2,576 \mathrm{t}_{\text {-Tabel }} \alpha 0,05 \%=1,645 \mathrm{t}$-Tabel $\alpha 0,1 \%=1,282$

Tingkat efisiensi biaya rata-rata yang dicapai 1,286 , artinya bahwa secara keseluruhan rata-rata keuntungan yang dicapai oleh usaha penggemukan sapi potong adalah $128 \%$ dari frontiernya yakni keuntungan maksimum yang dapat dicapai dengan sistem pengelolaan yang baik.

\section{Analisis Efisiensi Usahatani Integrasi Jagung-Sapi}

Apabila nilai efisiensi teknis (ET) lebih besar dari satu (ET >1) dapat diartikan bahwa penggunaan faktor produksi $\mathrm{X}$ belum efisien, sedangkan apabila nilai lebih kecil dari $1(\mathrm{ET}<1)$, maka dapat diartikan bahwa penggunaan faktor produksi $X$ tidak efisien. Sedangkan Efisiensi Ekonomi adalah merupakan hasil kali antara seluruh efisiensi teknis dengan efisiensi harga dari seluruh faktor input $(\mathrm{EE}=\mathrm{ET} \times \mathrm{EH})$. Apabila 
nilai $\mathrm{EE}>1$ maka dikatakan tidak efisien.

Tabel 5. Nilai Efisiensi Teknis, Efisiensi Harga dan Efisiensi Ekonomis Usahatani Integrasi Jagung-Sapi di Kabupaten Kupang, 2010.

\begin{tabular}{llcc}
\hline \multirow{2}{*}{ No } & Efisiensi & \multicolumn{2}{c}{$\begin{array}{c}\text { Nilai Efisiensi } \\
\text { Komoditas }\end{array}$} \\
\cline { 3 - 4 } & & Jagung & Sapi \\
\hline 1 & Efisiensi Teknis (ET) & 0,957 & 0,999 \\
2 & Efisiensi & 1,034 & 0,820 \\
& Alokatif/Efisiensi Harga & & \\
& (EA) & & \\
3 & Efisiensi Ekonomi (EE) & 0,990 & 0,820 \\
\hline
\end{tabular}

Sumber: Data primer diolah, 2011

Hasil analisis menunjukan bahwa tingkat efisiensi teknis yang dicapai oleh usahatani jagung dan sapi adalah 0,957 dan 0,999, artinya rata-rata produktivitas yang dicapai oleh usahatani ini adalah 95\% dan 99\% dari frontiernya yakni produktivitas maksimum yang dapat dicapai dengan sistem pengelolaan yang baik.

Rata-rata efisiensi harga (alokatif) diperoleh dari usahatani integrasi jagung-sapi adalah 1,034 dan 0,820, dapat dikatakan bahwa efisiensi alokatif jagung tidak efisien $(\mathrm{EH}>1)$. Artinya terdapat in-efisiensi biaya. Untuk itu diupayakan pengurangan sebagian biaya input-input produksi, sedangkan usaha ternak sapi potong lebih efisien dibanding jagung karena $\mathrm{EH}<1$.

Efisiensi ekonomis usahatani integrasi jagung-sapi diperoleh adalah 0,990 dan 0,820, sehingga usahatani jagung dan usaha penggemukan sapi potong secara ekonomi dikatakan efisien, sehingga nilai input produksi perlu dipertahankan.

\section{Analisis Daya Saing Jagung-Sapi}

Analisis daya saing komoditas pada system usahatani integrasi jagung-sapi di Kabupaten Kupang dapat diukur dengan analisis PAM (keunggulan komparatif dan kompetitif). Keunggulan komparatif dapat diukur dengan menggunakan nilai keuntungan sosial (KS) dan rasio biaya domestik (DRC). Sedangkan keunggulan kompetitif suatu komoditas dapat dilihat berdasarkan indikator-indikator Keuntungan Privat (KP) dan Rasio Biaya Privat (PCR).

Tabel 6. Analisis PAM Usahatani Integrasi Jagung-Sapi di Kabupaten Kupang, 2010.

\begin{tabular}{crrccc}
\hline \multicolumn{2}{c}{ PAM } & \multicolumn{3}{c}{ PAM TABLE } & \\
\hline \multirow{2}{*}{ JAGUNG } & Tahun 2010 & & & & Kentungan \\
DAN & Private & 45.512 .893 & 11.335 .591 & 13.148 .139 & 21.029 .163 \\
SAPI & Social & 27.922 .941 & 11.587 .279 & 4.163 .080 & 12.172 .583 \\
& Divergences & 17.589 .952 & $(251.687)$ & 8.985 .059 & 8.856 .581 \\
\hline
\end{tabular}

Sumber: Data primer diolah, 2011

Hasil analisis menunjukkan bahwa keuntungan privat petani peternak adalah $\mathrm{Rp}$ 21,029,163 per unit usahatani. Melihat nilai keuntungan privat yang bernilai positif berarti bahwa usahatani integrasi jagung-sapi memiliki keunggulan kompetitif cukup tinggi, sebab secara teknis dapat dikatakan efisien dan secara finansial menguntungkan. Baris kedua merupakan estimasi keuntungan sosial atau daya saing dalam keunggulan komparatif yang tercermin dari keuntungan sosial yang diperoleh yakni Rp 12,172,583. Sedangkan nilai divergensi merupakan selisih antara penerimaan privat dengan penerimaan sosial yakni Rp 17,589,952.

Pada kolom keuntungan nilai divergensi merupakan selisih antara keuntungan privat yakni $\mathrm{Rp}$ 8,856,581. Hal ini menunjukan bahwa walaupun selisih antara nilai tradable input privat dan nilai sisial bernilai negatif, namun keuntungan tetap bernilai positif, sehingga dapat dikatakan bahwa usahatanii jagung tetap memberikan daya saing bagi petani.

\section{a. Analisis Keunggulan Kompetitif}

Analisis keunggulan kompetitif suatu komoditas dapat dilihat berdasarkan indikatorindikator Keuntungan Privat (KP) dan Rasio Biaya Privat (PCR). Indikator tersebut menunjukkan tingkat keuntungan secara finansial dan tingkat efisiensi penggunaan sumberdaya.

Besaran nilai KP usahatani integrasi jagungsapi Rp 21.029.163. PCR (Private Cost Ratio) adalah rasio biaya domestik terhadap nilai tambah dalam harga privat. Besaran nilai PCR adalah 0.535 , ini berarti bahwa sistem usahatani integrasi jagung-sapi mampu membiayai faktor domestiknya pada harga privat. Dengan nilai PCR lebih kecil dari satu $(\mathrm{PCR}<1)$, maka usahatani dikatakan efisien secara finansial dan memiliki keunggulan kompetitif serta petani mampu 
membiayai faktor domestiknya pada harga privat.

\section{b. Analisis Keunggulan Komparatif}

Keunggulan komparatif dapat diukur dengan menggunakan nilai keuntungan sosial (KS) dan rasio biaya domestic (DRC). Keuntungan sosial usahatani integrasi jagung-sapi adalah $\mathrm{Rp}$ $12,172,583$. Keuntungan Sosial yang bernilai positif (KS > 0) menunjukkan bahwa usahatani integrasi jagung-sapi secara ekonomi menguntungkan namun tetap diperlukan intervensi pemerintah.
Nilai DRC yang diperoleh untuk usahatani integrasi jagung-sapi adalah 0,333 . Nilai tersebut mengindikasikan bahwa usahatani integrasi jagung-sapi memiliki keunggulan komparatif (daya saing) karena nilai DCR lebih kecil (DCR < 1). Nilai DRC yang lebih kecil dari PCR (DRC < PCR) berarti bahwa kebijakan pemerintah tidak meningkatkan daya saing dalam sistem usahatani integrasi jagung-sapi di Kabupaten Kupang dan tanpa adanya kebijakan usahatani integrasi jagung-sapipun masih menguntungkan dan layak untuk dijalankan.

Tabel 7. Indikator Analisis PAM Usahatani Integrasi Jagung-Sapi di Kabupaten Kupang, 2010.

\begin{tabular}{clc}
\hline No & Indikator & Nilai \\
\hline 1 & Keuntungan Privat = KP (A-B-C) & 21.029 .163 \\
2 & Keuntungan Sosial (E-F-G) & 12.172 .583 \\
3 & Koefisien Proteksi Output Nominal = NPCO [A/E] & 1,758 \\
4 & Koefisien Proteksi Input Nominal = NPCI [B/F] & 0,695 \\
5 & Rasio Biaya Privat = PCR [C/(A-B)] & 0,535 \\
6 & Rasio Sumberdaya Domestik = DRC [G/(E-F)] & 0,333 \\
7 & Koefisien Proteksi Efektif = EPC [(A-B)/(E-F)] & 4,349 \\
8 & Koefisien Keuntungan = PC [D/H) & 4,142 \\
9 & Rasio Subsidi Produsen = SRP [L/E] & 0,317 \\
10 & Transfer Output (OT) & 17.589 .952 \\
11 & Transfer Input (IT) & -251.687 \\
12 & Transfer faktor (TF) & 8.985 .059
\end{tabular}

Sumber: Data primer diolah, 2011

\section{Analisis Kebijakan Pemerintah a. Kebijakan Output}

Kebijakan pemerintah dalam hal output dapat dilihat dari dua indikator yaitu transfer output (TO) dan koefisien proteksi output nominal (Nominal Protection Coefficient Outputs/NPCO). Nilai Koefisien proteksi output nominal (NPCO) adalah rasio antara penerimaan berdasarkan harga privat dengan permintaan berdasarkan harga sosial. Nilai NPCO usahatani integrasi jagungsapi sebesar 1,758, artinya pemerintah memberikan proteksi pada usahatani jagung dan usaha penggemukan sapi potong pada system usahatani integrasi jagung-sapi di Kabupaten Kupang dengan cara menaikkan harga output di atas harga efisiensinya.

\section{b. Kebijakan Input}

Kebijakan pemerintah tidak hanya berkaitan dengan output saja, melainkan juga kebijakan yang berkaitan dengan input. Kebijakan pemerintah terhadap input produksi dapat dilihat dari nilai transfer input (TI), Transfer Faktor (TF), dan Koefisien Proteksi Nominal pada Input (Nominal Protection Coefficient on Inputs/NPCI). Koefisien proteksi input nominal (NPCI) adalah rasio antara biaya input tradable berdasarkan harga privat dan biaya input tradable berdasarkan harga sosial. Nilai NPCI usahatani integrasi jagung-sapi adalah 0,695 yang berarti pemerintah meningkatkan harga input tradable di pasar domestik yang dihadapi pada sistem usahatani integrasi jagung-sapi di Kabupaten Kupang berada di bawah harga dunia. Nilai NPCI $<1$ menunjukkan adanya proteksi pemerintah terhadap produsen input tradable di pasar domestik.

Transfer faktor (TF) yang merupakan perbedaan harga privat dengan harga sosial yang diterima oleh petani untuk pembayaran faktor produksi domestik. Nilai TF pada usahatani integrasi jagung-sapi ini adalah $\mathrm{Rp}$ 8.985.059, yang menunjukkan bahwa harga input domestik yang dikeluarkan pada tingkat harga privat lebih tinggi dibandingkan dengan biaya domestik yang dikeluarkan pada tingkat harga ekonomi. Artinya, 
adanya kebijakan pemerintah yang bersifat melindungi input domestik, misalnya subsidi kepada produsen input domestik yang digunakan untuk usahatani.

\section{c. Kebijakan Input-Output}

Analisis kebijakan Input-Output merupakan analisis gabungan antara analisis input dan output. Analisa kebijakan input-output antara lain Koefisien Proteksi Efektif (Effective Protection Coefficient/EPC), Transfer Bersih (TB), Koefisien keuntungan (Profitability Coefficient/PC), dan Rasio Subsidi Produsen (SRP).

Koefisien proteksi efektif (EPC) merupakan indikator dari dampak keseluruhan kebijakan input dan output terhadap system usahatani integrasi jagung-sapi di Kabupaten Kupang. Nilai EPC menggambarkan sejauh mana kebijakan pemerintah bersifat melindungi atau menghambat produksi domestik. Adapun nilai EPC yang dihasilkan dalam penelitian ini adalah lebih dari satu, dimana besaran nilai EPC usahatani integrasi jagung-sapi yaitu 4,349, yang menunjukkan bahwa adanya proteksi pemerintah dalam sistem usahatani integrasi jagung-sapi di Kabupaten Kupang.

Rasio subsidi produsen (SRP) menunjukkan proporsi penerimaan harga sosial pada usahatani integrasi jagung-sapi. Besarnya nilai SRP usahatani integrasi jagung-sapi adalah 0,317 yang berarti bahwa kebijakan pemerintah yang berlaku selama ini menyebabkan usahatani integrasi jagung-sapi di Kabupaten Kupang mengeluarkan biaya lebih rendah 0,317 persen dari biaya opportunity cost untuk berproduksi. Dengan demikian, kebijakan pemerintah yang ada secara tidak langsung menguntungkan bagi pengembangan dan peningkatan daya saing usahatani integrasi jagung-sapi di Kabupaten Kupang.

\section{KESIMPULAN}

Berdasarkan hasil penelitian dapat disimpulkan beberapa hal sebagai berikut:

1. Produksi jagung dipengaruhi oleh penggunaan input seperti; luas lahan, benih, pupuk kandang, pupuk Urea, pupuk SP36, pupuk KCL, pestisida, dan tenaga kerja. Sedangkan produksi sapi potong dipengaruhi oleh penggunaan input seperti pedet sapi, tebon jagung, jerami, hijauan lain, obat-obatan, vitamin dan produksi jagung. Hasil penelitian menunjukan bahwa dengan meningkatnya produksi jagung akan menyebabkan produksi sapi meningkat, sebaliknya meningkatnya jumlah ternak sapi menyebabkan produksi jagung ikut meningkat, karena limbah ternak yang dihasilkan dapat digunakan untuk memupuk tanaman jagung.

2. Hasil pendugaan fungsi produksi dan fungsi produksi stocastik frontier menunjukan bahwa usahatani integrasi jagung-sapi secara teknis telah efisien, dengan nilai efisiensi teknis ratarata usahatani jagung adalah 0,957, sedangkan untuk ternak sapi potong adalah 0,999, akan tetapi secara alokatif dan ekonomis belum efisien, karena penggunaan input yang berlebihan. Faktor umur, pendidikan, pengalaman dan jumlah tanggungan keluarga tidak berpengaruh terhadap efisiensi teknis usahatani.

3. Hasil pendugaan fungsi biaya dan fungsi biaya frontier menunjukan bahwa nilai rata-rata efisiensi biaya (cost efficiency) usahatani integrasi jagung-sapi lebih besar dari satu $(\mathrm{CE}>1)$ yakni 1,009 untuk usahatani jagung dan 1,286 untuk usaha sapi potong. Artinya penggunaan biaya faktor produksi pada usahatani integrasi jagung-sapi harus dikurangi agar dapat mencapai efisiensi yang optimal.

4. Hasil PAM menunjukan bahwa keuntungan privat yang diperoleh adalah $\mathrm{Rp} 21.029 .163$ per unit usahatani, keuntungan social sebesar $\mathrm{Rp}$ 12.172.583, sedangkan nilai divergensi adalah $\mathrm{Rp}$ 8.856.581. Hal ini mengindikasikan bahwa usahatani integrasi jagung-sapi di Kabupaten Kupang harus mengeluarkan biaya lebih atas faktor domestik dibanding dengan biaya faktor input tradable. Alasan yang menjadi penyebab utama adalah adanya kebijakan mengenai upah minimun.

5. Besaran nilai rasio biaya privat (PCR) usahatani integrasi jagung-sapi adalah 0,535 lebih kecil dari satu. Artinya bahwa usahatani integrasi jagung-sapi efisien secara finansial atau memiliki keunggulan kompetitif dan dapat memacu pertumbuhan produksi. Sedangkan nilai rasio sumberdaya domestic (DCR) adalah 0,333. Hal tersebut mengindikasikan bahwa usaha ini efisien secara ekonomik atau memiliki keunggulan komparatif.

6. Hasil analisis korelasi antara nilai efisiensi dan daya saing (DCR) sistem usahatani integrasi jagung-sapi mencerminkan bahwa besaran 
nilai koefisien korelasi efisiensi bernilai negative yang berada dibawah $\alpha=0.05$. Sehingga dapat dijelaskan pula bahwa rasio efisiensi dan daya saing jagung-sapi tidak memiliki hubungan yang kuat.

\section{DAFTAR PUSTAKA}

Adnyana, M.O., dan Kariyasa, K, 2003. Dampak dan Persepsi Petani Terhadap Penerapan Sistem Pengelolan Tanaman Terpadu Padi Sawah. Penelitian Pertanian Tanaman Pangan V 25 No.1 tahun 2003.

Basuki T, dkk. 2009. Kajian Model Pengembangan Teknologi dan Managemen Pola Integrasi Jagung - Sapi Menunjang Perbaikan Kinerja Usahatani Lahan Kering di Propinsi Nusa Tenggara Timur (NTT).

Battese, G. E. 1992. Frontier Production Function and Technical Effeciency: A Survey of Empirical Applications in Agricultural Economics. Journal of Agricultural Economics. 7 (1): 185-208.

Coelli, T. 1996. A Guide to FRONTIER Version
4.1: A Computer Program for Stochastic Frontier Production and Cost Function Estimation. Centre for Efficiency and Productivity Analysis, University of New England, Armidale.

Krugman, Paul, R, dan Obstfeld, Maurice, 2000. Ekonomi Internasional Teori dan Kebijaksanaan, Jakarta: Rajawali Press.

Simanjuntak, S. B. 1992. Analisis Daya Saing dan Dampak Kebijakan Pemerintah Terhadap Daya Saing Perusahaan Kelapa Sawit Indonesia. Disertasi Doktor Program Pasca Sarjana. Institut Pertanian Bogor. Bogor.

Simatupang, P. 1991, The Conception of Domestic Resource Cost and Net Ekonomic Benefit for Comparative Advantage Analysis Agribusiness Division Working Paper No. 2/91, Center for Agro-Socioeconomic Research. Bogor.

Sudarsono, 1995. Pengantar Ekonomi Mikro. Penerbit LP3ES Jakarta. 